\title{
Leptonemella species (Desmodoridae, Stilbonematinae), benthic marine nematodes with ectosymbiotic bacteria, from littoral sand of the North Sea island of Sylt: taxonomy and ecological aspects
}

Received: 28 November 2002 / Revised: 28 March 2003 / Accepted: 9 April 2003 / Published online: 10 May 2003

(C) Springer-Verlag and AWI 2003

\begin{abstract}
Leptonemella species represent a dominant element of the nematode fauna in sulfidic, deep sediment layers on the sandy shore of Sylt. Based on collections sampled here in 1991-1999, a taxonomic treatise is presented on the three co-existing species, Leptonemella aphanothecae Gerlach, 1950, the closely related L. vicina sp. nov., and L. gorgo Gerlach, 1950. The high incidence of pseudohermaphrodites in the material, mostly functional females with a male copulatory apparatus, is remarkable. The highest population densities of Leptonemella spp. (up to 73 individuals $/ 10 \mathrm{ml}$ sand) were found near polychaete burrows. Because of the great spatial and temporal variations in the oxygen/sulfide regime of these microhabitats, and because of the strong adhesive capabilities of Leptonemella spp., which can anchor themselves firmly to sand grains using caudal glands, we propose that a hemisessile life strategy is employed by these nematodes to fulfill the metabolic needs of their sulfide-oxidizing ectosymbionts.
\end{abstract}

Keywords Leptonemella spp. (Nematoda, Desmodoridae) - Taxonomy · Bionomics · Sulfide-oxidizing ectosymbiotic bacteria . Pseudohermaphrodites

\section{Introduction}

The Stilbonematinae comprise a group of very slender, benthic nematodes that carry a conspicuous, dense cover

Communicated by K. Reise

F. Riemann (屯)

Alfred-Wegener-Institut für Polar- und Meeresforschung,

Am Handelshafen 12, 27570 Bremerhaven, Germany

e-mail: friemann@awi-bremerhaven.de

F. Thiermann $\cdot$ L. Bock

Zoologisches Institut und Zoologisches Museum,

Hamburg University,

Martin-Luther-King-Platz 3, 20146 Hamburg, Germany of symbiotic bacteria on the cuticle, giving the hosts a strange, bright white appearance in incident light. About 30 species of these nematodes have been described from many places around the world. They live in sheltered intertidal and subtidal sulfidic sediments, mainly at the interface between the oxidized surface layer and the deeper, anoxic sediment (Ott and Novak 1989; Ott et al. 1991). The symbiotic, uniform bacteria which colonize the surface of the worms in various characteristic patterns are chemoautotrophic oxidizers of sulfide and other reduced sulfur compounds (Schiemer et al. 1990; Polz et al. 1992, 1994; Hentschel et al. 1999). The nematodes appear to graze on their symbionts (Polz et al. 1992; Hoschitz et al. 2001), and it has been suggested that the bacterial coat is protective against toxic hydrogen sulfide (Ott 1995; Hentschel et al. 1999).

In many collections, Stilbonematinae have only been found in small numbers, but Ott and Novak (1989) discovered a habitat where these nematodes represent the dominant element of the meiofauna. They found comparatively large Stilbonematinae at a high species diversity (at least eight species from five genera) and at a high population density in the depths of calcareous sand in the shallow subtidal on the Belize Barrier Reef. Nematodes from this Caribbean site, in addition to supplementary material from the Mediterranean Sea, yielded the main material basis for many morphological, taxonomic and ecophysiological studies by Jörg Ott from the University of Vienna and his collaborators.

Stilbonematinae tend to be most abundant in subtropical and tropical calcareous sediments, especially coralline sands, because the deposition of large, autochthonous grains at sheltered sites provide the unusual combination of extensive interstitial spaces and reduced conditions, thus allowing the development of a rich thiobios that may also be favored by the spatial complexity of the interface between oxidized and reduced layers (Ott and Novak 1989). In 1991, Olav Giere from the Zoological Institute of the University of Hamburg, together with his collaborators during a students' excursion to a sheltered sandy 
shore of the North Sea island of Sylt, discovered another, easily accessible location with a surprisingly rich population of Stilbonematinae that yielded the material for the present paper. The subfamily was represented exclusively by members of the genus Leptonemella Cobb, 1920, with at least three co-existing species. In this site, quartz sand provided the habitat for the sulfide fauna in deeper layers. The peculiar presence of coarse and medium sand in a rather sheltered position is due to the aeolian introduction of dune sand (Bayerl et al. 1998).

The generic type species, L. cincta Cobb, 1920, was described from "sand, Ocean Beach, Miami, Florida", and there has subsequently been much research on Leptonemella species with no mention of their abundance in sulfidic sediments. The first indication of the association of Stilbonematinae in general with reducing sediment conditions was given by Ott and Schiemer (1983). Jensen (1987a), by analysing the vertical distribution pattern of nematodes in fine sand in the Øresund in Denmark, documented the preferred habitat of $L$. aphanothecae in a 13-14 cm sediment depth having a pronounced odor of $\mathrm{H}_{2} \mathrm{~S}$. Earlier, Gerlach (1950) described L. aphanothecae from coarse sand and L. gorgo from coarse and fine sand from the Kiel Bight sublittoral and noted their peculiar prokaryotic symbionts. In 1958, Gerlach reported the frequent occurrence of Leptonemella in sandy bottoms of the area. In a sublittoral bay in Massachusetts, Wieser (1959) observed the co-occurrence of three Leptonemella species in samples under surface areas of only $10 \mathrm{~cm}^{2}$. Each species was found to be associated with a characteristic prokaryote, which, according to the assumption of Wieser, could be ingested by the nematodes. Warwick (1981) envisaged that such intimate and specific relationships with microbial populations indicate mechanisms that maintain a high diversity of meiofauna species. Regrettably, Wieser (1959) did not supplement his investigations with a taxonomic study of the stilbonematine nematodes. It appears that Leptonemella species may offer a feasible way to test theories of possible niche partitioning and the co-evolution of hosts and symbionts, and to discover mechanisms that generate and maintain the diversity of the nematode fauna.

The Sylt Leptonemella habitat is adjacent to the laboratory facilities of the Wattenmeerstation in List. The convenient access to the sulfide biota prompted the launch of several research projects conducted by members of the University of Hamburg (Zoological Institute), the Max Planck Institute for Marine Microbiology in Bremen, and the Alfred Wegener Institute in Bremerhaven. Major topics are the geochemistry of the pore waters, zoological and microbiological investigations with particular consideration of the sulfidic layers and the sulfur cycle, identification of the Leptonemella species and their symbionts, and the evaluation of the geochemical relevance of the symbionts of Leptonemella compared to free sulfide-oxidizing bacteria.

In the present paper, we redescribe $L$. aphanothecae Gerlach, 1950 and L. gorgo Gerlach, 1950 and describe $L$. vicina sp. nov. from Sylt. We then present and discuss ecological data and observations of their habits.

\section{Materials and Methods}

The investigation site is a rippled sandflat below the bend of the steep beach face, close to the mid tide level (tidal water level range about $1.8 \mathrm{~m}$ ), situated adjacent to the Wattenmeer Research Station in List on the island of Sylt ("Hausstrand", $55^{\circ} 5^{\prime} \mathrm{N} / 8^{\circ} 26^{\prime} \mathrm{E}$ ). The beach and flat have been the focus of exhaustive meiofaunal surveys during the last 30 years, summarized by Armonies and Reise (2000) with an introduction to the topography and physiography. Comprehensive descriptions of biotic and abiotic processes in the Sylt wadden area have been edited by Gätje and Reise (1998). The main collection area for Leptonemella is situated about $10-30 \mathrm{~m}$ off the bend of the beach and is populated by the polychaete Arenicola marina. The area is sheltered, yet there is little organic material in the quartz sediment. The habitat consists of well-sorted sand with a mean grain size of $379 \mu \mathrm{m}$ (Bock 1999). Under a 3- to 5-cm-thick, yellow surface layer we found a dark sulfidic layer in October 1999. The thickness of the bright surface layer was different at the various sampling times and at different places in the sandflat. In vertical sections we often observed a speckled or striped brownish coloration in the black layer caused by worm tubes (A. marina and other polychaetes). Sometimes we noted an odor of $\mathrm{H}_{2} \mathrm{~S}$ in samples containing Leptonemella individuals.

All samples were taken during low tide on the exposed sandflat. For the general collection of nematodes, portions of sand from different sediment depths were washed and decanted with seawater on the shore or in the laboratory. Determinations of the population density and vertical distribution of the nematodes were made using clear plexiglass corers with a diameter of $5 \mathrm{~cm}$ which were usually pushed up to $20 \mathrm{~cm}$ into the sand. The cores were extruded immediately after their recovery and sliced into sections. For live observations of the nematodes in their natural microhabitats under the dissection microscope, and subsequent determinations of their numbers, we used small, clear plexiglass tubes ('minicorer', length $5 \mathrm{~cm}$, diameter $2.4 \mathrm{~cm}$, volume $22.6 \mathrm{ml}$ ), which were closed with polyethylene caps.

Because Leptonemella species discharge sticky secretions from their caudal glands anchoring the worms firmly to sand grains, we applied various extraction methods. Quantitative extractions were attempted: (1) with long-term elutriations of formalin-fixed material, (2) with repeated washing and decanting of live material with seawater, or (3) by applying sequences of first washing the sediment with seawater, followed by short-term cold freshwater washing, before the nematodes were brought into seawater again. In addition, the contents of four minicorers were hand-picked directly, without prior washing procedures. For this method, small portions of fixed material were stained with Rose Bengal dissolved in alkaline formaldehyde before being sorted.

The material was usually fixed with $4 \%$ formaldehyde solution; a few specimens that were needed for bacteriological investigations were fixed in ethanol. For critical taxonomic purposes, we preferred to inject the living, isolated nematodes with a pipette into a hot (about $80^{\circ} \mathrm{C}$ ) $5 \%$ formaldehyde solution in seawater. This procedure prevents to some extent the formation of compact, cylindrospiral coilings of the very slender worm body, which often preclude the examination of diagnostic characters. A special mixture of fixatives (stock solution containing 5\% formaldehyde, $0.5 \%$ propionic acid, $28 \%$ ethanol) was added to a number of other samples, either sediment bulk samples or decantates of washing procedures; the effective concentration was about one third or one half of the stock solution. After 0.5 or $1 \mathrm{~h}$ of fixation, we replaced the fixative with the undiluted stock solution. Specimens processed in this way showed good anatomical preservation (see Figs. 2 and 5). Some material collected by Olav Giere, fixed with a mixture of formaldehyde and glutaraldehyde, was also used. Permanent microscope mounts were made in glycerin after the slow evapo- 
ration method (Riemann 1988). Microscopic observations, drawings and photographs (with Nomarski techniques) were made using Zeiss Standard and Zeiss Axioplan microscopes. Reference material is deposited in the Nematode Collection of the former Institut für Meeresforschung Bremerhaven at the Alfred Wegener Institute (NSIMB 574/1-8), which is intended for inclusion in the collections of the Zoological Museum of the University of Hamburg after the termination of nematological work in Bremerhaven.

For the taxonomic part of our study, we examined a selection of slides with glycerin-mounted material collected from the Sylt littoral area and additional material from the sublittoral of the Kiel Bight (Baltic Sea). The relevant selection from Sylt comprised 202 individuals (71 L. aphanothecae, $94 \mathrm{~L}$. vicina sp. nov., 14 L. gorgo, 2 Leptonemella sp.) collected between 1991 and 1999. Part of the material was collected by Olav Giere and members of his working group and part by Nicole Dubilier. For comparison, Sievert Lorenzen supplied material (9 L. aphanothecae, $14 \mathrm{~L}$. gorgo, $1 \mathrm{~L}$. vicina, 3 Leptonemella sp.) determined by him from a collection made by Wilfried Scheibel in 1969 in the Kiel Bight (Scheibel 1973).

\section{Taxonomic descriptions}

Leptonemella aphanothecae Gerlach, 1950

See Figs. 1A-D; 2A-C; 5E, F

Male $_{1}$ and male $_{2}$ (NSIMB 574/1 and 574/2): Sylt 22 June 1992, coll. Riemann. Female 1 (NSIMB 574/3): Sylt 24 June 1992, coll. Riemann.

Fig. 1A-D Leptonemella aphanothecae Gerlach, 1950. Anterior end of male $_{1}(\mathbf{A})$; posterior end of male 1 (B); mature sperm in front of vas deferens, male $_{1}(\mathbf{C})$. Head of male $_{2}$, setae depicted as seen in perspective distortion (D)

\section{Morphometric data}

Male $_{1}: L=2370 \mu \mathrm{m} ; a=87.8 ; b=20.4 ; c=20.3$ (where $L=$ total body length; $a=L$ divided by maximum body diameter; $b=L$ divided by pharyngeal length; $c=L$ divided by tail length); spicules $37 \mu \mathrm{m}$ on the chord. Male $_{2}$ : $L=3000 \mu \mathrm{m} ; a=111 ; b=20.8 ; c=24.2$; spicules $37 \mu \mathrm{m}$ on the chord. Female $1: L=3550 \mu \mathrm{m} ; a=101.4$; $b=25.9 ; c=31.7 ; V=48.6 \%(V=$ percentage between total length and distance of vulva from the anterior end).

\section{Description of a male}

Male $_{1}$, Fig. 1A-C; data from other specimens in square brackets. Body very slender, cylindrical, with a slight constriction behind the head capsule, tail cylindroconical. The cuticle is somewhat irregularly annulate; the annulation begins immediately behind the head capsule with about 11 rings per $10 \mu \mathrm{m}$. This distance is occupied by 14 rings in the middle of the body and about 11 rings on the middle of the tail. In the optical section, the contours of the cuticle of the midbody region appear smooth; in the cervical region and on the tail the annulation shows deep constrictions. Tail cone (ca. $20 \mu \mathrm{m}$ ) without annules. Width of cephalic capsule $27 \mu \mathrm{m}$, capsule with a faint granulation (at a moulting juvenile, stage IV individual, it

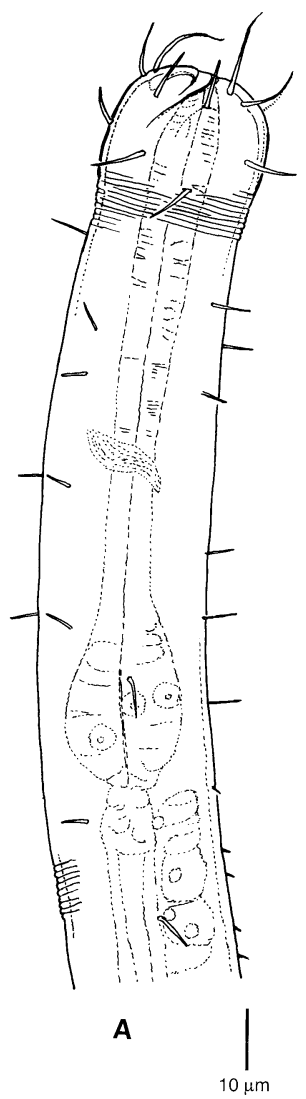

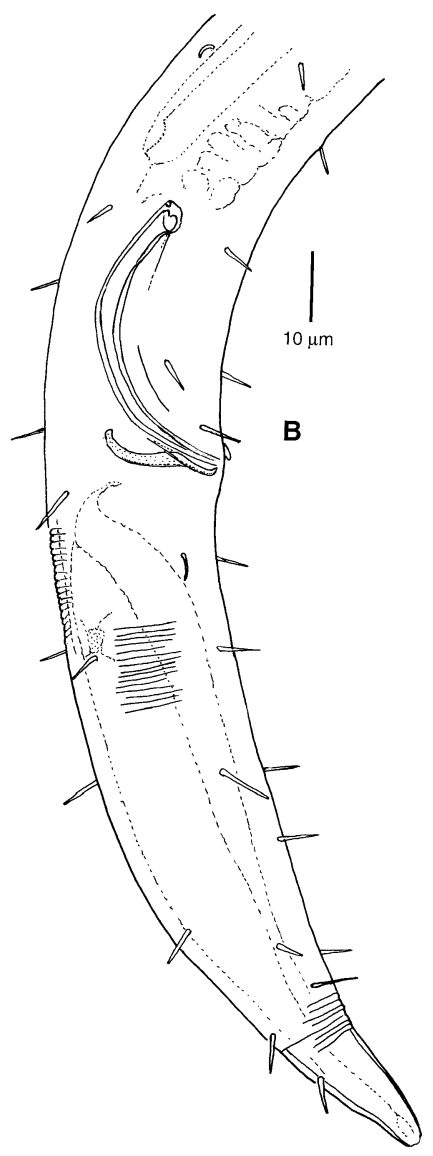

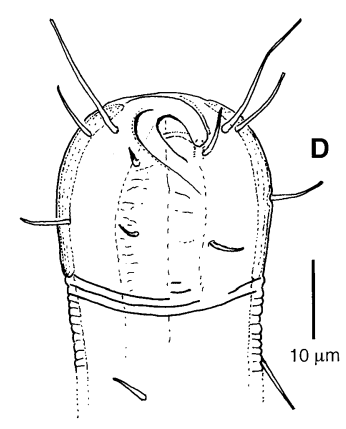



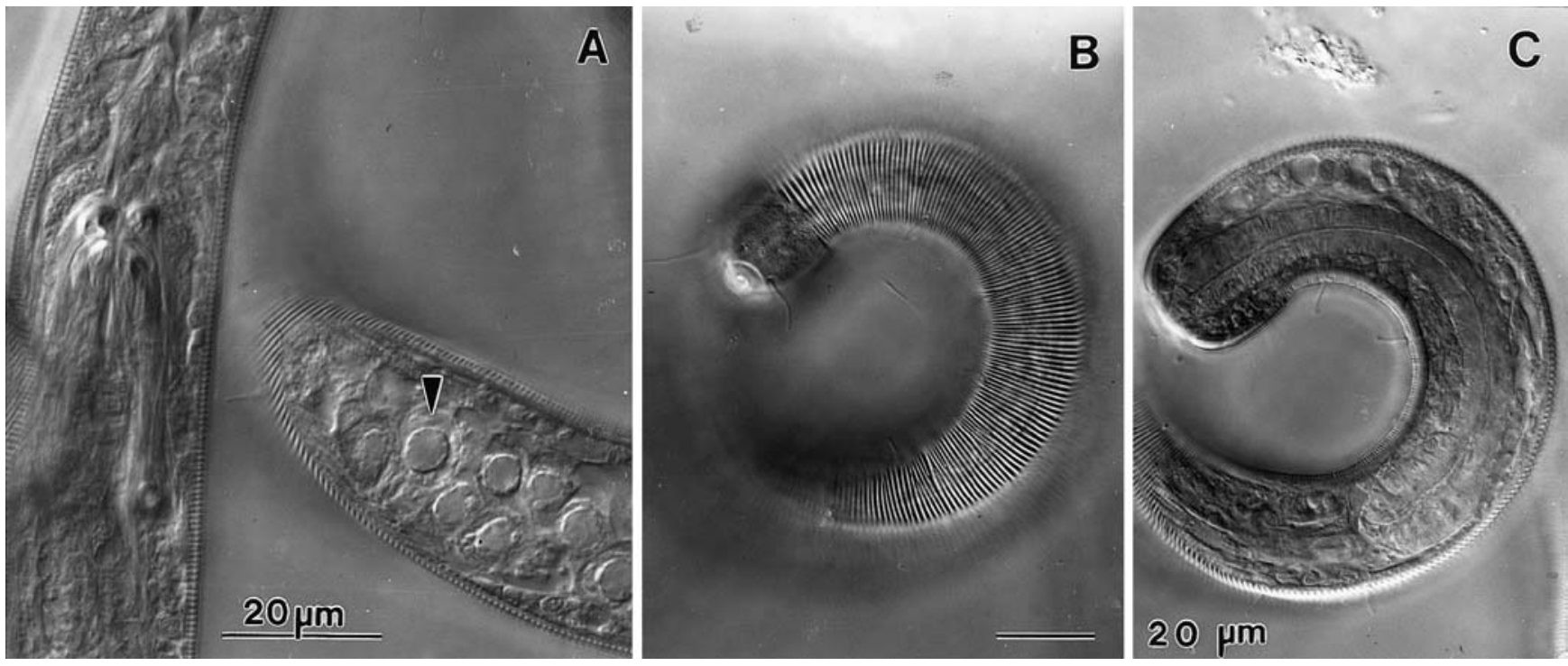

Fig. 2A-C L. aphanothecae Gerlach, 1950. Spicular apparatus in ventral view and mature sperm (arrow) of male 2 (A). Anterior end, surface view $(\mathbf{B})$ and optical section $(\mathbf{C})$ of female 1

was seen that the granules represent vertical rods in the thick capsule). Amphids (fovea) shepherd's crook-shaped with strongly light-refracting contours at the anterior end and a slightly shallowing ventral furrow, which can be traced backwards beyond the middle of the head capsule. Four thin cephalic setae reaching $15 \mu \mathrm{m}$ in length (up to $18 \mu \mathrm{m}$ in male $_{2}$ ), followed by eight anterior subcephalic setae, about $10 \mu \mathrm{m}$ long, four of which are almost on the same level as the cephalic setae, but thinner; the other four setae located level with the amphideal pore. Posterior circle of subcephalic setae close to the posterior end of the head capsule, reaching about $8 \mu \mathrm{m}$. The anterior somatic setae immediately behind the capsule are about $6 \mu \mathrm{m}$ long. Setae in the cervical region with blunt tips. Behind the oesophageal bulb there is a ventral row $(90 \mu \mathrm{m}$ in length) of 12 thin bristles, about $2-3 \mu \mathrm{m}$ in length, with an irregular spacing. Comparatively few (interspaces 30$40 \mu \mathrm{m})$ somatic setae, arranged in dorsal, ventral and sublateral rows, thin, $5 \mu \mathrm{m}$ long. Setae on the tail up to $8 \mu \mathrm{m}$ long.

Buccal cavity almost invisible, with no teeth. Oesophageal bulb oval; nerve ring in the middle of the oesophagus.

The single testis and the seminal duct are situated to the left of the intestine. Mature sperm in seminal vesicle containing a roundish, almost hollow central structure, about 5-7 $\mu \mathrm{m}$ in diameter, with strongly light-refractive walls which show irregular thickenings. This structure is surrounded by a pale plasmatic envelope. Spicules with slightly cephalate proximal ends. The gubernaculum is a spoon-shaped structure with paired, dorsally directed, bow-shaped apophyses. Tail 4.3 anal diameters long.

\section{Bacteria}

The intestine of male ${ }_{1}$ is filled with coccoid bacteria, but the typical coat of ectosymbiotic bacteria is lacking in this and many other specimens. A few specimens are covered partially with a multilayered coat of coccoid bacteria (length 1-2 $\mu \mathrm{m}$ ). Because these ectosymbionts are often found to be preserved only in the centre of tightly coiled worms, we assume that usually most ectosymbionts were stripped from the nematode cuticle during preparation.

\section{Description of females}

Females are similar to the males with regard to body shape, cuticular annulation and setosity (except of the lack of special postcervical bristles). Adjacent to the vulva and extending $150-160 \mu \mathrm{m}$ to the anterior and the posterior region of the body there is a conspicuous bright zone in which the body is filled with large glands (Fig. $5 \mathrm{E}, \mathrm{F})$. The glands open through compressed pores which are located in the thick cuticular rings.

\section{Pseudohermaphrodites}

The Sylt material examined for taxonomy contained 13 pseudohermaphrodites ("intersexes"); additional aberrant specimens have been observed during the sorting and counting of other material from the same collection site. Of the available pseudohermaphrodites, 11 specimens belong to $L$. aphanothecae, 2 specimens are $L$. vicina $\mathrm{sp}$. nov. Most of the individuals are morphological and functional females with ovaries; even inseminated sperm have been observed in the uteri. One specimen has no 


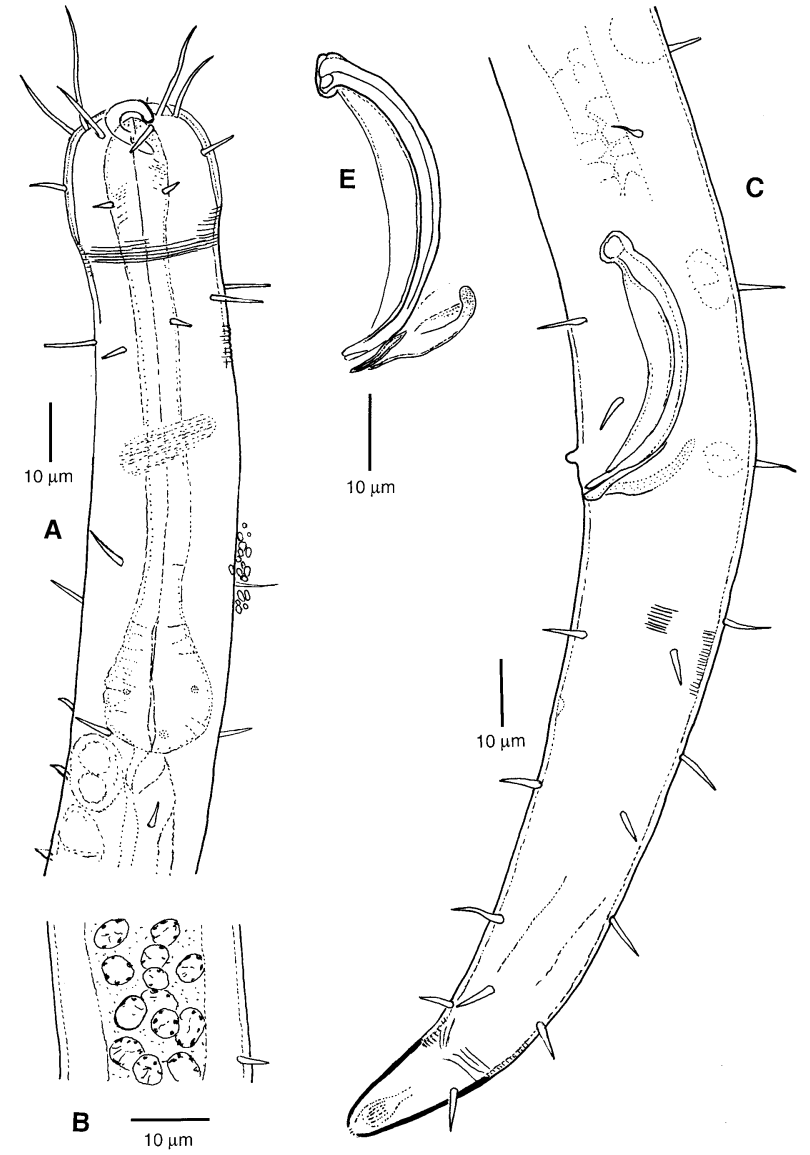

Fig. 3A-I L. vicina sp. nov., male $_{1}$, holotype (A-D). Anterior end (A); mature sperm (B); posterior end (C); total view showing bacterial coat (D). Spicular apparatus of male $_{3}$, paratype $(\mathbf{E})$; oblique view of head, male $_{3}(\mathbf{F})$. Female 1 , allotype $(\mathbf{G}-\mathbf{I})$. Vulvar

ovaries: instead, aggregations of small bacteria have been seen in the region where the germinal zone is normally situated. In the anal region of the pseudohermaphrodites, a spicular apparatus is present. In some cases, the spicular apparatus has the normal shape found in males, sometimes reductions have been seen like the absence of gubernacular structures or malformation of one spicule. There were no testes or seminal ducts in these specimens. In one sample (collected in September 1992 by Inez Gamenick) containing 52 Leptonemella specimens, six pseudohermaphrodites were been found. This is a very high and unexplainable incidence of that anomaly; "intersexes" in marine nematodes are usually rare (Gourbault and Vincx 1990).

\section{Diagnostic characters}

Leptonemella aphanothecae is characterized by the coarse cuticular annulation and by comparatively thin and short cephalic (up to $20 \mu \mathrm{m}$ ) and subcephalic setae (length less than $20 \mu \mathrm{m})$.
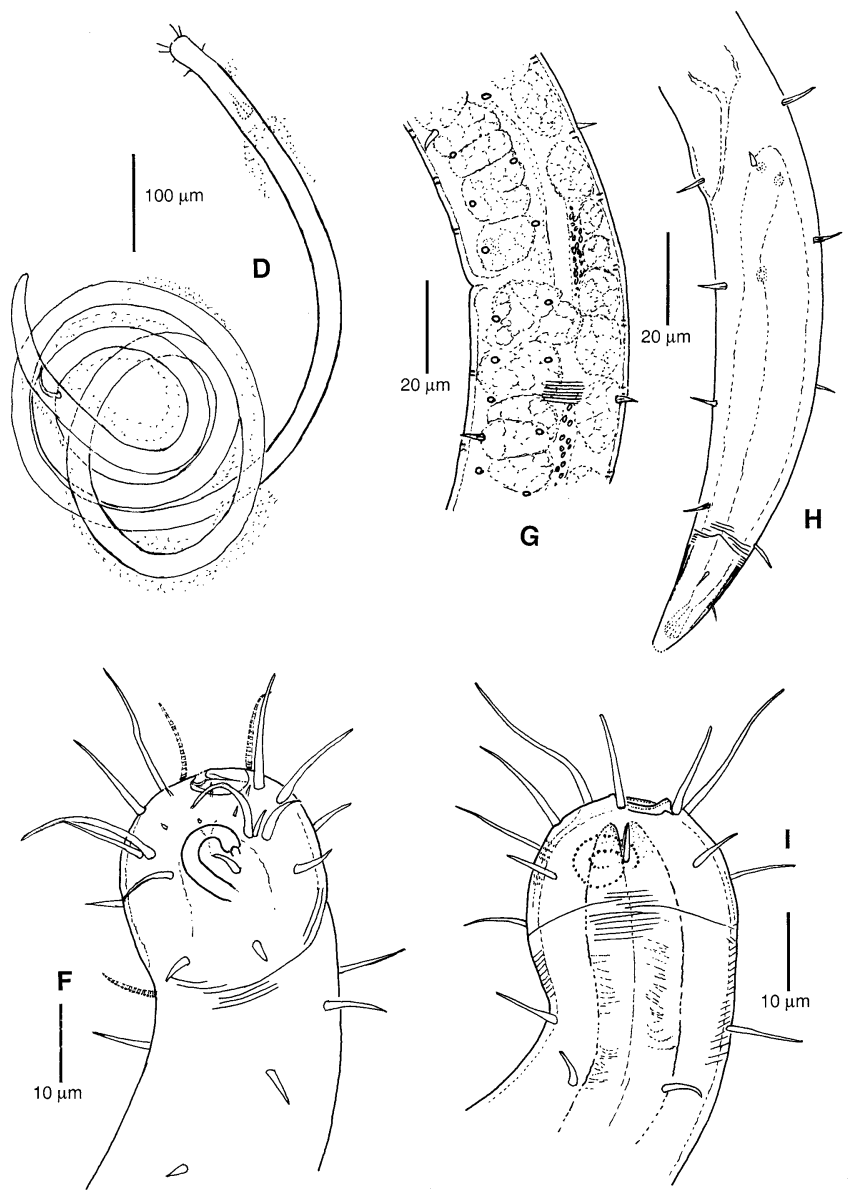

region with large glands and their ringpores on the cuticle $(\mathbf{G})$; tail $(\mathbf{H})$; head in oblique view, with the contours of the right amphid depicted as a dotted spiral (I)

\section{Leptonemella vicina $\mathrm{sp}$. nov.}

See Figs. 3A-I; 4A, B; 5A-D

Male $_{1}$ (holotype, NSIMB 574/4), male 2 and male 3 (paratypes, NSIMB 574/5 and 6). Female ${ }_{1}$ (allotype, NSIMB 574/6): Sylt March 1999, coll. Thiermann. Type locality: Sylt, adjacent to the Wattenmeerstation in List.

Etymology: From vicinus, Latin for neighbour, used as adjective, referring to the often found association with $L$. aphanothecae.

\section{Morphometric data}

Male 1 (holotype): $L=2685 \mu \mathrm{m} ; a=107.4 ; b=24.5 ; c=23.1$; spicules $39 \mu \mathrm{m}$ on the chord. Male $_{2}: L=2375 \mu \mathrm{m} ; a=99.0$; $b=22.4 ; c=24.2$; spicules $39 \mu \mathrm{m}$ on the chord. $\mathrm{Male}_{3}$ : $L=2900 \mu \mathrm{m} ; a=116 ; b=25.4 ; c=22.3$; spicules $40 \mu \mathrm{m}$ on the chord. Female 1 : $L=3010 \mu \mathrm{m} ; a=83.6 ; b=24.1 ; c=27.9$; $V=50 \%$. 

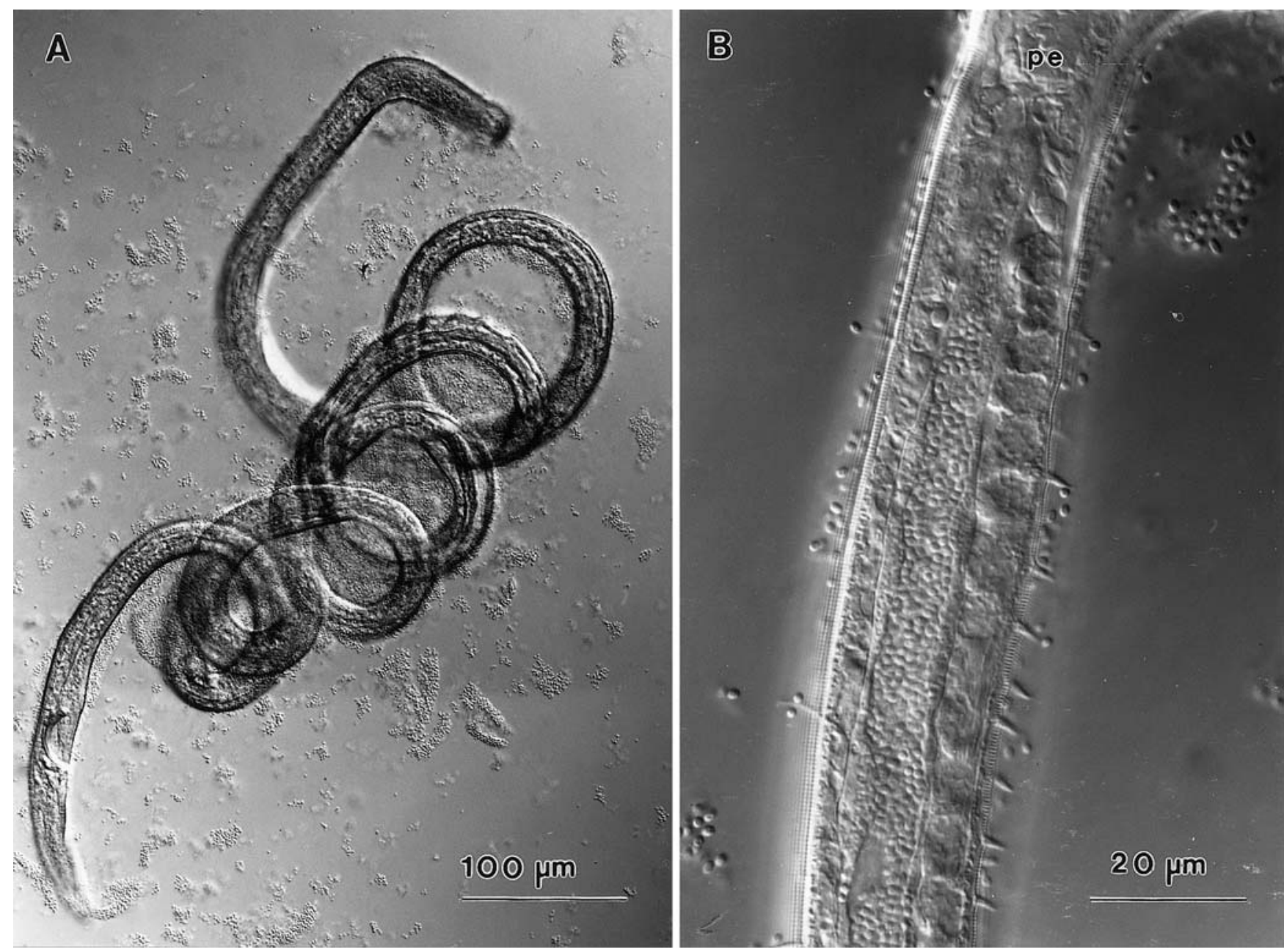

Fig. 4A, B L. vicina sp. nov., male 2 , paratype. Total view, with masses of bacteria detached during the preparation (A); body region behind the end of oesophagus (pe) showing dense accumulation of bacteria in the intestine and the ventral row of cuticular spines (B)

\section{Description of a male}

Holotype, Fig. 3A-D. Body very slender, with a broadened head, tail cylindroconical. Cuticle covered by a thick layer of coccoid bacteria. The cuticle is somewhat irregularly annulate; the annulation begins immediately behind the head capsule with about 15 rings per $10 \mu \mathrm{m}$. In the postcervical region, this distance is occupied by 16 rings, and there are 17 rings on the middle of the tail. In the optical section, the contours of the tail region cuticle appear smooth when examined with the bright field microscope (slight constrictions visible with interference contrast only), as compared with the anterior body where the contours appear annulate. Tail cone ca. $17 \mu \mathrm{m}$ long, without annules. Width of cephalic capsule $27 \mu \mathrm{m}$, capsule with a faint granulation, but without pores. Amphids (fovea) shepherd's crook-shaped with strongly light-refracting contours at the anterior end. Corpus gelatum in the fovea with distinct ciliary filaments. Lip papillae (i.e. the first circle of cephalic sensory organs) invisible. Before the anterior margins of the amphids there are minute bristles (i.e. second circle, equivalent to the head papillae). Four anteriorly directed cephalic setae, reaching $22 \mu \mathrm{m}$ in length, followed by eight subcephalic setae, up to $13 \mu \mathrm{m}$ long, four of which are on almost the same level as the cephalic setae, but slightly thinner; the other four setae located level with amphideal pore [the setosity pattern in male $_{3}$, because of the oblique view, could not be analysed]. As an exception, an additional small seta was seen in dorsolateral position near the amphideal pore, see Fig. 3F. A second circle of subcephalic setae surrounding the middle of the cephalic capsule reaching about $7 \mu \mathrm{m}$. The anterior somatic setae immediately behind the capsule are up to $9 \mu \mathrm{m}$ long, thick, with blunt tips .[in another male $10 \mu \mathrm{m}$ long], other setae in the cervical region reaching $7 \mu \mathrm{m}$. Beginning at the oesophageal bulb there is a ventral row $(210 \mu \mathrm{m}$ in length) of short thick spines, $3 \mu \mathrm{m}$ long, resembling saw teeth, the spacing of which is about $10 \mu \mathrm{m}$ This region is followed by a $75 \mu \mathrm{m}$ long transition zone in which the saw teeth are replaced by gradually more slender setae [the spine zone may extend in other individuals up to $300 \mu \mathrm{m}$, containing 30 spines]. More posteriorly there are ventral and dorsal rows of slightly curved setae, about 


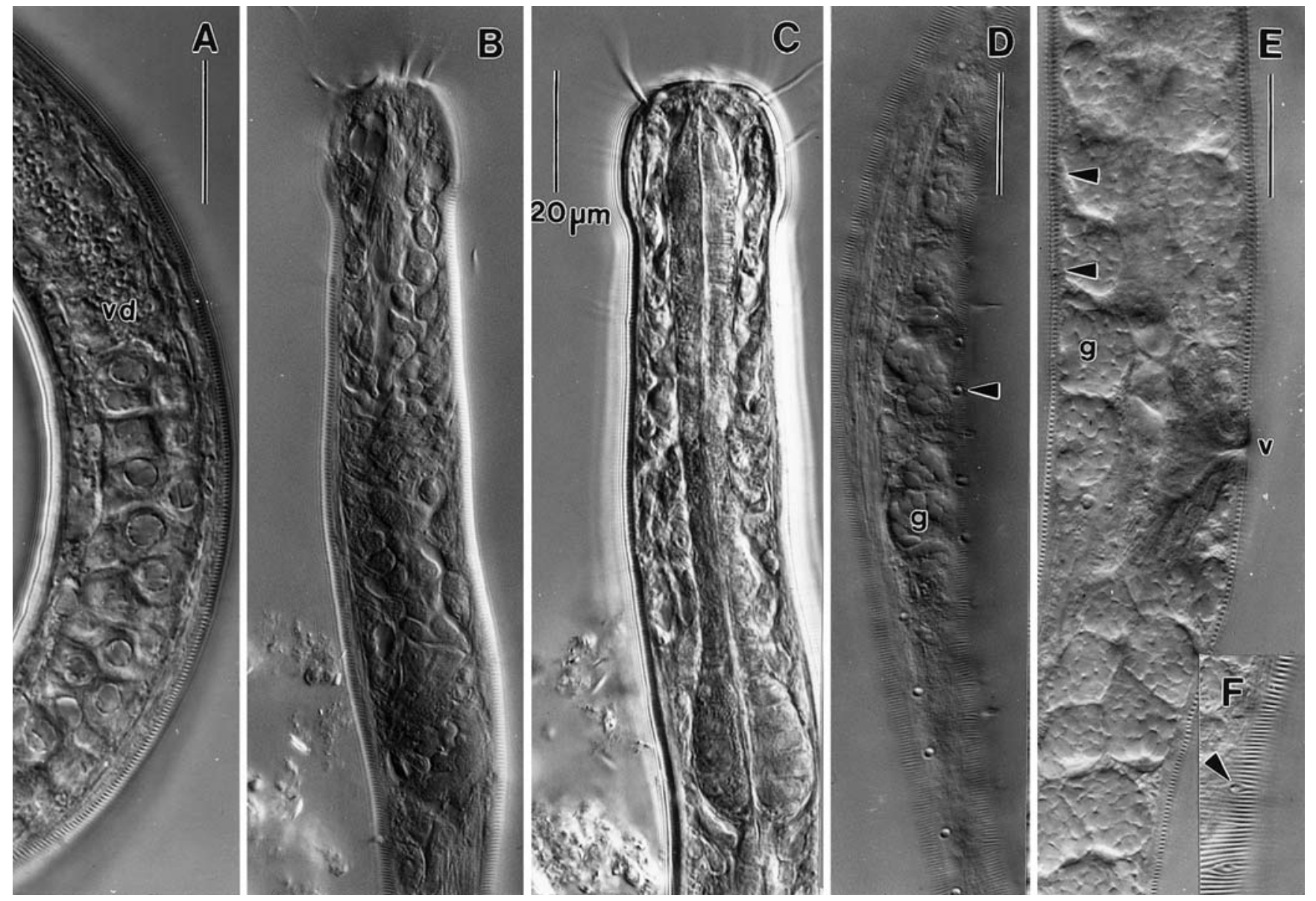

Fig. 5A-F L. vicina sp. nov. (A-D). Mature sperm in a male close to the vas deferens $(v d, \mathbf{A})$. Anterior end of a female at a high (B) and a low focus $(\mathbf{C})$; vulva region of same female, showing large glands $(g)$ and their ring-shaped pores (arrow) in the cuticle (D). $L$. aphanothecae Gerlach, 1950, female $1(\mathbf{E}, \mathbf{F})$. Vulva $(v)$ region with large glands $(g)$ and their cuticular pores (arrows); insert (F) shows the cuticular surface
$5 \mu \mathrm{m}$ [up to $6 \mu \mathrm{m}$ ] in length, with a thick base. In addition, there are sublateral rows of widely spaced setae. All these setae, including the saw-tooth ones (Fig. 4B), appear to be connected with gland cells ("glandular sensory organs", Bauer-Nebelsick et al. 1995). Setae on the tail stronger than the anterior ones, $8 \mu \mathrm{m}$ long. No gland cells were observed beneath the posterior tail setae.

Buccal cavity amost invisible, with no teeth. Oesophageal bulb pyriform; nerve ring in the middle of the oesophagus.

The single testis and the seminal duct are situated to the left of the intestine [in another male in the same slide: to the right side]; germinal zone about $1100 \mu \mathrm{m}$ behind the anterior end. Growth zone and seminal vesicle extend about $525 \mu \mathrm{m}$ backward, followed by a glandular vas deferens. Mature sperm in seminal vesicle containing a roundish, almost hollow central structure, about $5 \mu \mathrm{m}$ in diameter, with strongly light-refractive walls which show irregular thickenings. Spicules with a broad velum and cephalate proximal ends [according to different perspectives and individual variations, the shape of the cephalate ends appears very different in the material, sometimes distinct ventrally bent hammer-shape expansions have been observed]. The gubernaculum is a spoon-shaped structure with paired, dorsally directed, bow-shaped apophyses. Tail 4.3 anal diameters long.

\section{Description of females}

The females resemble the males in general appearance: there is, however, a glandular zone in the middle of the body, which extends from the vulva over a distance of about $120 \mu \mathrm{m}$ to the anterior and to the posterior end. This zone, which is visible at low magnifications, contains large bright glands that open through conspicuous cuticular, circular ring pores arranged in six (subdorsal, lateral, and subventral) rows. Amphids in a frontal position, being strongly sclerotized spirals with two turns. The head setae in female reach $_{2} 22 \mu \mathrm{m}$, but in other females they may reach a length of up to $25 \mu \mathrm{m}$. Body setosity similar to males, but the somatic setae are stronger in some specimens and arranged at shorter, irregular distances (about $15-30 \mu \mathrm{m})$ and slightly longer $(6 \mu \mathrm{m})$ than in the 


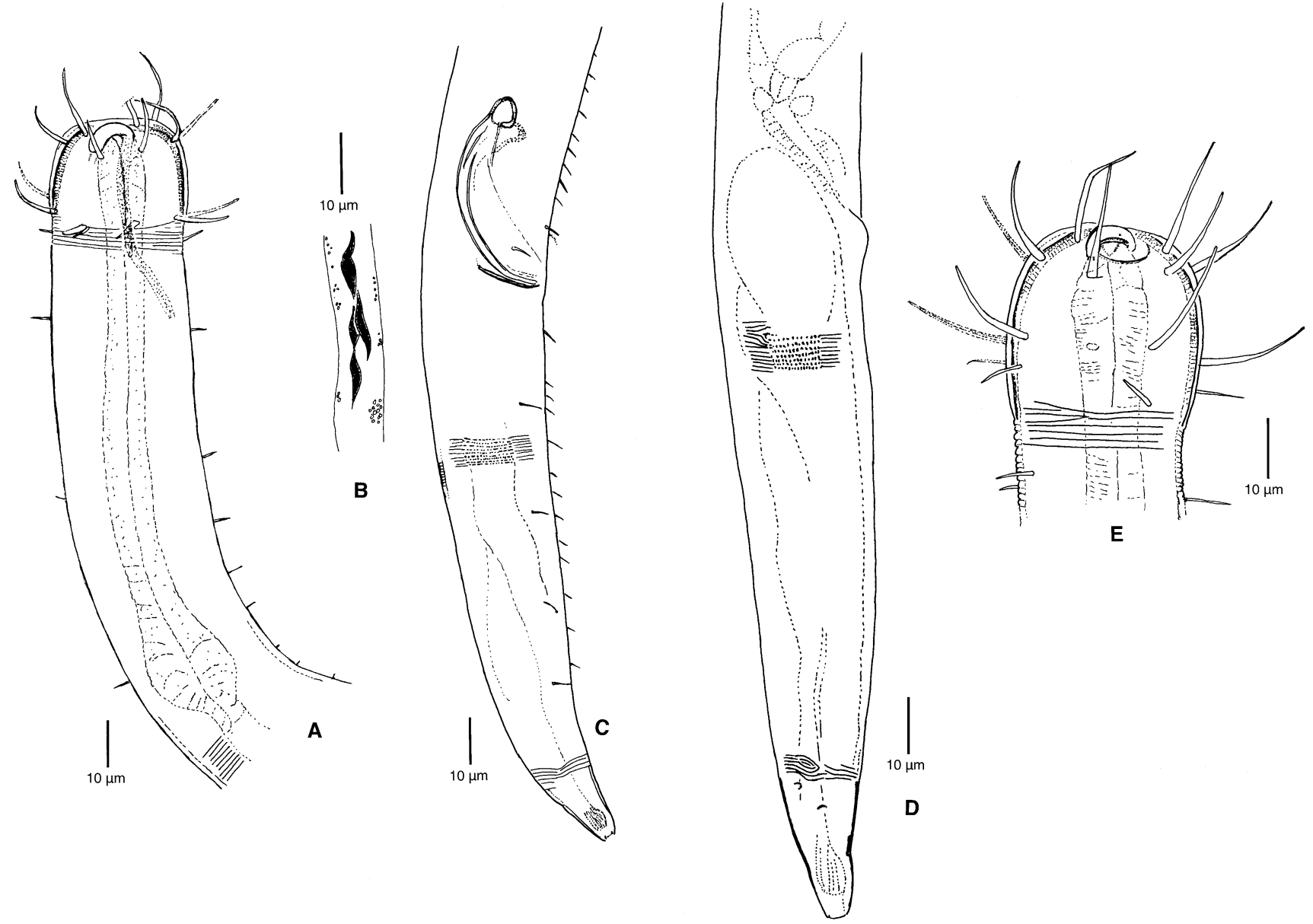

Fig. 6A-E L. gorgo Gerlach, 1950. Anterior end of male 1 (A); sperm in vas deferens (B); posterior end of male 1 (C). Tail (D) and head (E) of female 1

males. Row of postcervical spines lacking. Gonads situated to the left of the intestine, paired, opposed, reflexed. Eggs up to $260 \mu \mathrm{m}$ long. Tail length about 4.6 anal body widths. Tail cone without annules about $24 \mu \mathrm{m}$ (up to $28 \mu \mathrm{m}$ ) long.

For pseudohermaphrodites, see "Leptonemella aphanothecae Gerlach, 1950”.

\section{Diagnostic characters}

Leptonemella vicina is characterized by the fine annulation showing almost no cuticular constrictions on the middle of the tail; the contour appears to be smooth. Males with a postcervical ventral row of thick, short spines. Females with rows of conspicuous cuticular ring pores in the glandular zone near the vulva.

Leptonemella gorgo Gerlach, 1950

See Figs. 6A-E; 7A-C.
Male $_{1}$ (NSIMB 574/7): Sylt July 1992, coll. Thiermann. Female ${ }_{1}$ and female 2 (NSIMB 574/8): Sylt 24 June 1992, coll. Riemann.

\section{Morphometric data}

Male $_{1}: L=2890 \mu \mathrm{m} ; a=96.3 ; b=21.9 ; \quad c=22.9 ;$ spicules $41 \mu \mathrm{m}$ on the chord. Female $1: L=3875 \mu \mathrm{m} ; a=102$; $b=27.5 ; c=32.3 ; V=50 \%$. Female $2: L=4650 \mu \mathrm{m} ; a=105.7$; $b=31.2 ; c=35.8 ; V=49 \%$.

\section{Description of a male}

Male $_{1}$, Fig. 6A-C. Body slender, with a cylindroconical tail and a slightly broadened head capsule. Cuticle annulate (somewhat irregularly) behind this capsule; immediately behind the head with about 12 rings per $10 \mu \mathrm{m}$, about 14 rings per $10 \mu \mathrm{m}$ on the middle of the body and the middle of the tail. In the optical section, the contours of the cuticle of the midbody and midtail region 

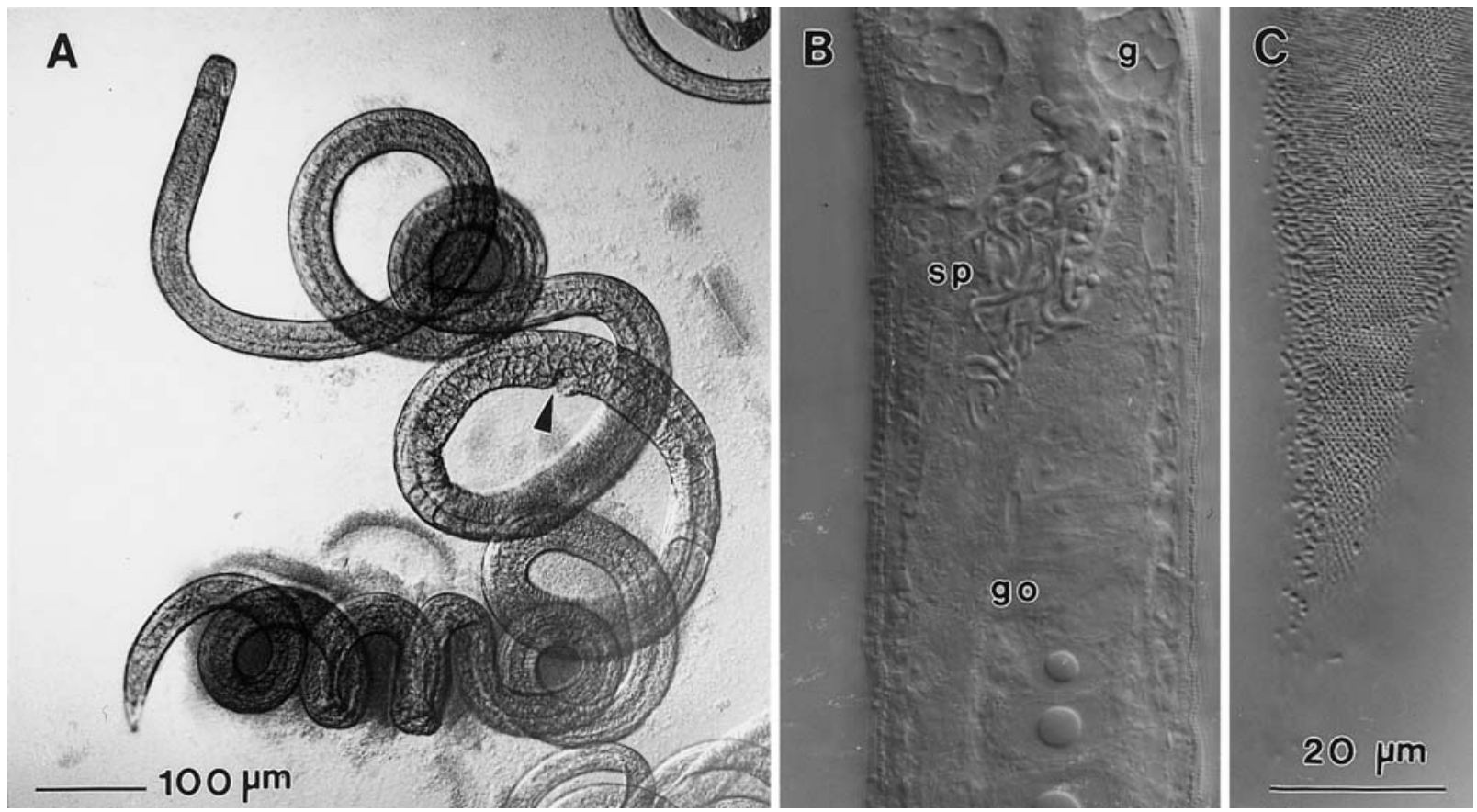

Fig. 7A-C L. gorgo Gerlach, 1950. Total view of a female with bacterial coat $(\mathbf{A})$. Arrow points to the vulva (posterior lip slightly damaged). Inseminated sperm $(s p)$ in a female close to the

appear smooth. Tail cone ca. $15 \mu \mathrm{m}$ long, without annules. Lateral field with a $10 \mu \mathrm{m}$ broad, punctate pattern of annules, which begins about $50 \mu \mathrm{m}$ behind the cardia [in other males $25 \mu \mathrm{m}$ or $80 \mu \mathrm{m}$ ] and extends almost to the tail cone. Width of cephalic capsule $30 \mu \mathrm{m}$. Amphids (fovea) horseshoe-shaped with comparatively thin contours, fading at the ventral posterior end, where on either side a $70 \mu \mathrm{m}$ long corpus gelatum emanates. Four cephalic setae reaching $20 \mu \mathrm{m}$ in length, followed by an anterior circle of subcephalic setae, about $15 \mu \mathrm{m}$ long [other male: $19 \mu \mathrm{m}$ ], four of which are at the level of the posterior border of the fovea. Posterior circle of subcephalic setae close to the posterior margin of the cephalic capsule, reaching $13 \mu \mathrm{m}$ (other male: $16 \mu \mathrm{m}$ ) in length. All cephalic setae with a soft appearance, partially flattened. Cervical setae about $5 \mu \mathrm{m}$ long, three postcervical thin short bristles located ventrally immediately behind the oesophageal bulb. No other somatic setae present, except those on the tail.

Stoma small, funnel-shaped, unarmed. Oesophageal bulb elliptical, comparatively small.

The single testis (germinal zone $1407 \mu \mathrm{m}$ behind anterior end) and the seminal duct are situated ventral to the intestine. Sperm in seminal vesicle elongate, strongly light-refractive. Spicules with cephalate proximal ends (there is a great variability in form and light refraction of these ends in other males). Gubernaculum straight, slender, strongly light-refractive. Tail 4.5 anal diameters long. Preanal 11 short $(2-3 \mu \mathrm{m})$ bristles in a ventral row, postanal 13 bristles [in other males 7 and 9; 7 and 16; 7 and $15 ; 7$ and 9$]$. germination zone of posterior ovary ( $g o$ ) and the large advulvar glands $(g, \mathbf{B})$; cuticle of this specimen with punctate lateral field and ectosymbiotic bacteria $(\mathbf{C})$

\section{Description of a female}

Female $_{1}$, Fig. 6D, E. Cephalic capsule $33 \mu \mathrm{m}$ broad. Amphids (fovea) in a frontal position, spiral with one turn. Cephalic setae up to $21 \mu \mathrm{m}$ (up to $22 \mu \mathrm{m}$ in another female), anterior and posterior subcephalic setae up to $20 \mu \mathrm{m}$ [the latter up to $22 \mu \mathrm{m}$ in the other female]; accessory setae behind posterior subcephalic setae $9 \mu \mathrm{m}$. Anterior cervical setae $7 \mu \mathrm{m}$. There are no postcervical setae. Two ovaries, reflexed, mature egg $155 \times 33 \mu \mathrm{m}$. Inseminated sperm long filiform (more elongate than those in the males). Extending from the vulva to either germinal zone there is a region (extending $144 \mu \mathrm{m}$ forwards and $160 \mu \mathrm{m}$ backwards) with conspicuous gland cells like those described for L. vicina, but the distribution of pores in the punctate lateral field varies, as there are pores in somewhat irregular sublateral and in lateral positions. Tail length about 4.8 anal body widths. Female ${ }_{1}$ and female ${ }_{2}$ are infected by masses of bacteria in the body wall.

\section{Description of juveniles (material from the Kiel Bight)}

Cuticle of larval stage IV of males (sperm already present) and females homogeneously annulate. The characteristic punctation of the lateral field appears only in adults, as was verified by the observation of a moulting female. 


\section{Diagnostic characters}

Leptonemella gorgo is characterized by the elongate, strongly light-refractive sperm and by the cuticular punctation of the lateral field.

\section{Ecological aspects}

Abundance and vertical distribution of Leptonemella species.

Between February and July 1999 the sandy shore of the Sylt 'Hausstrand' was sampled at monthly intervals with corers $(5 \mathrm{~cm}$ diameter, $20 \mathrm{~cm}$ length; three replicates taken with 52-60 cm distance in between). Depth sections comprising the $0-2,2-5,5-10$ and $10-15 \mathrm{~cm}$ depth zones were sliced and the nematodes were isolated with the elutriation method after fixation. The results were presented in an unpublished thesis (Bock 1999) out of which we extract some data. In the surface $0-2 \mathrm{~cm}$ depth layer Leptonemella species were rare: only two individuals were collected in 18 cores. The preferred depth layer was the 5-10 cm layer. Here, the highest average population density of Leptonemella species was reached in March with 46.2 individuals/100 $\mathrm{ml}$ sand (in May and June on average only 10.9 individuals). The bulk of other nematode species occurred above this depth zone. In the $10-$ to $15-\mathrm{cm}$ layer, average densities of Leptonemella were 9.5 individuals $/ 100 \mathrm{ml}$ in June and 16.0 individuals in February. Later, during a campaign in June 2001, we examined long sediment cores for the lower depth range of the occurrence of Leptonemella and noticed single, living individuals down to $44 \mathrm{~cm}$ sediment depth.

The general depth distribution indicates a preference of Leptonemella species for a sulfidic environment. Measurements of sulfide concentrations conducted by Bock in extracted pore water samples showed low free sulfide concentrations that were below the detection limit of $2 \mu \mathrm{M}$ between March and June 1999 but, according to microelectrode measurements (Dirk de Beer, MPI Bremen, personal communication), patches with sulfide concentrations of $100-150 \mu \mathrm{M}$ have been located in the sampling area in June. During the processing of the samples, a distinct sulfide smell was occasionally noted. In laboratory experiments, individuals of Leptonemella revealed a high tolerance of hypoxia and high sulfide concentration. Preference tests (methods according to Ott et al. 1991) showed the preference of Leptonemella species for the chemocline in the oxygen/sulfide gradient system (Bock 1999).

Microhabitat studies - the significance of polychaete burrows

The highest population density found in a single core by Bock was in April 1999, when in the 5- to 10-cm depth section 57.1 Leptonemella/100 $\mathrm{ml}$ sand were counted.
One replicate, taken $60 \mathrm{~cm}$ distant from this collection site, yielded no representatives of the genus, yet another only $52 \mathrm{~cm}$ distant yielded 48.9 individuals. Corresponding figures for the 10- to $15-\mathrm{cm}$ layer were $0.0 ; 8.2$ and 32.6 individuals. These variations suggest habitat discontinuities with small patches containing high population densities of the nematodes. To examine this point during the following collection campaigns in October 1999 and in March 2000, we used clear plexiglass minicorers which allowed the observation of the sediment structures and biota under the dissection microscope.

In October 1999 we took minicorer samples with particular consideration for the transition zone in the sand between the bright, oxidized surface layer and the dark sulfidic layer down to about $10 \mathrm{~cm} ; 24$ minicores were microscopically inspected $4-17 \mathrm{~h}$ after retrieval. At the periphery of seven cores, 11 living Leptonemella were observed in the sand interstices. Occasionally, polychaete worm tubes were partially dissected by the corer, and in one case we observed three individuals of Leptonemella in the discoloration zone adjacent to a tube, in which for a short time a small crawling polychaete appeared. In another sample, two specimens were observed in a brightly colored area $6 \mathrm{~mm}$ distant from a vertical tube; the surrounding sediment was black.

One sample of blackish sand (7 October, 4-9 cm sediment depth, $20 \mathrm{ml}$ sediment), in which the brownish environment of a polychaete tube was longitudinally hit, displayed one lively active Leptonemella (see "Bionomics"). This sample was later fixed and stained with Rose Bengal (the other minicores of that campaign were not preserved). All nematodes were extracted under the microscope without prior washing or sieving. The sample contained 396 nematodes. Leptonemella aff. aphanothecae (including vicina) was the most abundant species group, with 146 individuals (36.9\% of all nematodes), followed by 38 Chromadoridae, 35 Spiriniinae, 32 Microlaiminae, 25 Monhysteroidea, and 22 Linhomoeidae.

Three minicorer samples taken in the Sylt site in March 2000 included wall material of Arenicola burrows in which the living polychaete was observed before the sampling. The population density of Leptonemella in these three cores amounted to 14, 25, and 31 individuals in about $20 \mathrm{ml}$ sediment (first two samples with freshwater elutriation of live material, the other sample processed as above). Two minicorer controls without recognizable burrows yielded 4 and 10 Leptonemellal $20 \mathrm{ml}$ sediment. Due to sediment disturbance after storms in the March 2000 campaign, the sulfide layer was not well differentiated from the overlying oxic sediment.

\section{Bionomics}

During the extraction of living Leptonemella species from the sediment, we noted the extreme stickiness of the caudal gland secretions with which these worms anchored themselves to sand grains. Often it was difficult to detach 
the worms from their substratum by pipette suction or with a needle. Upon disturbance they wind up into a compact small curl fixed to the sand grain, and this condition persists during the fixation process with formaldehyde or ethanol. Isolated specimens preserved in glycerin often showed a thick thread of the secretion emanating out of the caudal gland pores.

The inspection of microcorer samples under the dissection microscope revealed 11 Leptonemella individuals in their natural environment; 10 of these crawled into the interior of the core during the observation, but one individual was firmly anchored to a sand grain with the end of its tail (see "Microhabitat studies-the significance of polychaete burrows", 7 October 1999). The anchored worm was observed for over $4 \mathrm{~h}$ in dim light and the next morning, after an observation break of about $13.5 \mathrm{~h}$, it was found still there in an active condition, presumably sticking to the same grain. With the anterior end, the worm performed lively, wide, probing excursions into the environment, thereby sometimes touching the sand grains with the head. Often the body was stretched out almost full length, but there remained a few small coils of the body close to the tail end. Occasionally, the anterior end was retracted by coiling of the posterior end and serpentinous bends of the midbody, the worm then stretched the body again. After disturbance by our knocking the microcope stage, the worm rapidly formed a tight cylindrospiral curl, and resumed the search movements after $1 \mathrm{~min}$. After $4 \mathrm{~h}$ of observation, the worm showed short-term undulatory movements of the mid-body region for $2 \mathrm{~min}$ : these movements were repeated every $4 \mathrm{~s}$; the vigorous shaking of the body was reminiscent of a ventilating activity.

The layer of ectosymbiotic bacteria on the cuticle of the individual was almost intact over the full length of the body, the cover was stripped off only on a very short region (about $50 \mu \mathrm{m}$ ). The thickness of the bacterial cover was estimated to be half of the body diameter (i.e. diameter of the worm $25 \mu \mathrm{m}$, outer diameter of the microbial coat $50 \mu \mathrm{m}$ ). Though the cervical region of the worm was bent backwards like a hook, during the first hours of observation the head was not seen to contact the thick cover of bacteria on the body.

\section{Associations with bacteria}

Leptonemella species carry a multilayered coat of coccoid bacteria on the body surface (Figs. 4A, 7A) except over the head. In our material, the microbial coat on the cuticle of the individuals was often lacking after the extraction procedures or showed large regions of the body on which the bacteria were stripped off. Even active individuals observed in the minicores showed this damage to the ectosymbiont cover. Sometimes we observed bulges and depressions in the microbial layers. Obviously, the symbionts are very loosely attached to their host's cuticle and to one another, and in glycerin mounts they are easily swept away. Because of these conditions, we cannot assess the average thickness of the symbiont cover of undisturbed specimens: according to our estimates the figure is between 5 and $10 \mu \mathrm{m}$. Juveniles also carry ectosymbionts; the smallest specimen in our material, $600 \mu \mathrm{m}$ long, has a uniform layer 2-3 cells thick.

In many individuals of the three Leptonemella species, accumulations of uniform bacteria have been observed in the intestines (Fig. 4B); in a collection of $37 \mathrm{~L}$. aff. aphanothecae 16 specimens (43\%) contained these bacterial masses. The intestinal bacteria are very similar to the ectosymbionts on the cuticula. In most cases, the intestinal bacteria were concentrated in the anterior region of the intestine; only once were bacteria observed in the anal region. Besides bacteria, there were no other particulate contents visible in the intestinal lumen.

In four individuals of L. gorgo, another type of bacteria was found in the tissues of the body wall that they had obviously destroyed. The nematodes were therefore in a moribund condition. One pseudohermaphrodite of $L$. aphanothecae (see "Pseudohermaphrodites") contained aggregations of small bacteria in the gonad region.

\section{Discussion}

\section{Taxonomy}

To date, six species have been recognized as belonging to the genus Leptonemella (see Hoschitz et al. 1999) and to this number we add L. vicina sp. nov. There are only slight species differences, and these in our opinion present particular problems to the intuitive comprehension. Moreover, Leptonemella species tend to wind up in a compact curl thus obscuring anatomical details in the preparations and presenting essential characters in an unfavorable, distorted perspective. For the same reason, length measurements are problematic. Often the thick coat of ectosymbiotic bacteria impairs the visibility of details.

Hoschitz et al. (1999) based their compilation of diagnostic characters mainly on amphids, setosity, and the shape of the gubernacula. In consideration of these and other characters, and including L. vicina sp. nov., we give the following diagnostic annotations to the list of species:

Leptonemella cincta Cobb, 1920. According to Cobb (1920) there are no somatic setae, but there were several submedian, slender, tapering cuticular "thorns" seen on the tail, each about one quarter as long as the anal bodydiameter. In the redescription by Gerlach (1964) strong subdorsal and subventral caudal setae are depicted. The labial or second circle head papillae are distinct and setiform ( $3 \mu \mathrm{m}$ in Gerlach's description).

Leptonemella granulosa Boucher, 1975. In the male, there are two rows of short subventral setae on the tail, but there are no setae on the dorsal region with the exception of subterminal setae. It appears that the comparatively great length of the oesophagus is distinctive. For the quotient of the oesophageal length divided by the corresponding body width at the oesophageal base 
('cervical quotient') we calculate figures of 5.5, 5.9, and 6.3 from the dimensions presented by Boucher (1975).

Leptonemella juliae Hoschitz, Buchholz and Ott, 1999. Cephalic setae extremely long (30-32 $\mu \mathrm{m})$, long somatic setae $(10-13 \mu \mathrm{m})$. Cuticle with very fine annulation. Oesophagus short; the figure of the allotype shows a cervical quotient of about 3 [this figure is 3.4 on the electron micrograph presented by Hoschitz et al. (2001)].

Leptonemella vestari Hoschitz, Buchholz and Ott, 1999. The cervical quotient is 4.5. Oesophageal bulb very small, globular. Cephalic setae 15-17 $\mu \mathrm{m}$, subcephalic setae $10-13$ and $14-16 \mu \mathrm{m}$ long. Gubernaculum complex, angulated.

Leptonemella gorgo Gerlach, 1950. Cervical quotient 3.5 (Gerlach 1950) or 4.5 (present study). The elongate, strongly light-refractive sperm and the cuticular punctation on the annules of the lateral field are distinctive.

Leptonemella aphanothecae Gerlach, 1950. Cervical quotient 4-4.5. Oesophageal bulb oval. Comparatively weak and short cephalic (up to $20 \mu \mathrm{m}$ ) and subcephalic setae (length less than $20 \mu \mathrm{m}$ ). Cuticula with coarse annulation. Gubernaculum with paired, dorsally directed, bow-shaped apophyses.

Leptonemella vicina sp. nov. Cervical quotient about 4.5. Cuticula with very fine annulation showing almost no cuticular constrictions on the middle of the tail; the contour appears to be smooth. Males with a postcervical ventral row of thick, short spines. Gubernaculum with paired, dorsally directed, bow-shaped apophyses. Females with rows of conspicuous cuticular ring pores in the glandular zone near the vulva.

One of the species, Leptonemella aphanothecae Gerlach, 1950, has been redescribed in two publications. The single female specimen described by Luc and De Coninck (1959) has two subventral rows of ten setae on the tail. The male described by Platt and Warwick (1988) has a rounded projection on the gubernaculum, but no characteristic paired apophyses. It is possible that these individuals and other nematodes formerly identified as L. aphanothecae belong to a complex of several closely related species. From this still problematical complex we separated $L$. vicina because of the very fine annulation of the cuticle (this diagnostic character was not influenced by the various fixatives used). In addition, there is the shape of the postcervical spines of the males, which are more setose in L. aphanothecae. All setae of L. vicina are stronger than those of $L$. aphanothecae. The male amphideal fovea in L. vicina has a comparatively short, ventral groove. With regard to the very fine cuticular annulation, $L$. vicina is similar to $L$. juliae, but is distinguished by the comparatively long oesophagus and shorter cephalic and somatic setae.

Leptonemella gorgo Gerlach, 1950 has only been recorded subsequent to the original description by Scheibel (1973, p. 65), when he presented Lorenzen's determination of a selection of nematodes from the Kiel Bight, and by Lorenzen (1974, p. 316) from the North Sea near Helgoland. In an inventory of the nematodes from sublittoral regions of the Kiel Bight, Gerlach (1958, p. 75) treated this species in an ecological context indiscriminately together with $L$. aphanothecae. The most distinctive characters of the species are the shape of the sperm and the lateral differentiation of the cuticle; both characters had escaped the attention of former investigators. The elongate, strongly light-refractive sperm, which are easily detectable, also in inseminated females, are to our knowledge distinct from those in all other Desmodoridae. The cuticular rings are replaced on the lateral field by transverse rows of mushroom-shaped elements, which appear as a punctation pattern under the light microscope. Giere (1992, Fig. 9) published an instructive TEMmicrograph of a cross section of Leptonemella sp. that we identify as L. gorgo. For confirmation, Reinhard Windoffer from the working group of Olav Giere kindly showed us SEM-micrographs that show the lateral mushroom-shaped structures from specimens derived from the same collection in Sylt. Similar structures cover the cuticle of another, still undescribed Leptonemella species with a huge bacterial coat (Ott et al. 1982, Fig. 10a). In that species, sampled in Florida, the mushroomshaped structures extend over the whole cuticle (Ott, personal communication).

\section{Ecology}

Analyses of the population density of the Leptonemella species from Sylt revealed a patchy distribution in the sandflat ranging, for instance, from zero to 5.7 individuals $/ 10 \mathrm{ml}$ sand in three replicates taken with large corers [average 3.5: Bock (1999)]. Using minicorers at Sylt, we retrieved samples with higher concentrations of Leptonemella. The maximum density figure of 73 individuals $/ 10 \mathrm{ml}$ is of the highest ever recorded for Stilbonematinae. From the Belize Barrier Reef, average densities of stilbonematid species (five genera) of about 25 individuals $/ 10 \mathrm{ml}$ sediment and a maximum of 189 individuals $/ 10 \mathrm{ml}$ in areas with a high sulfide concentration just beneath the sediment surface ('hot spots') have been reported (Ott and Novak 1989; calculated from their Figs. 9 and 10). Jensen (1987a) found L. aphanothecae in the Danish Øresund at $15 \mathrm{~m}$ water depth in the sediment depth layer of 13-14 cm at a density of about 40 individuals $/ 10 \mathrm{ml}$ fine sand (calculated from his Fig. 1). The samples were collected very close to burrows of the lugworm Arenicola marina.

The association of Stilbonematinae with the tail shaft of A. marina burrows and other worm tubes had not been discovered to date. Our minicore examinations, however, give evidence that polychaete worm burrows are a preferred habitat of Leptonemella species, and the high population density reported by Jensen (1987a) adds to this suggestion. In general, there is a strong preference of the entire subsurface fauna for the vicinity of irrigated burrows (Reise 1981; Meyers et al. 1987). In a comprehensive investigation of the oxygen/sulfide regime and nematodes associated with lugworm burrows in the intertidal, Wetzel et al. (1995) conceived this habitat as 
permanently fluctuating, with drastic variations in the mm-range ideally meeting the requirements of 'sulfur bacteria'. Accordingly, the nematodes living around the tail shaft region would be alternately exposed to irregular changes in concentrations of sulfide and oxygen. Subtidally, in the absence of tidal water movements episodic fluctuations of the redox conditions in the interstitial system of sediments may be of less importance, but steep gradients in the mm-range do exist also there (see Meyers et al. 1987).

Chemoautotrophic sulfur bacteria like the symbionts on the cuticle of Stilbonematinae require reduced sulfur compounds as well as electron acceptors for their oxidation. According to observations on the vertical distribution of Caribbean Stilbonematinae (Laxus oneistus; Ott et al. 1995) in laboratory experiments, these nematodes expose their symbionts alternately to reducing or oxidizing conditions by migrations through the chemocline in both directions (Ott et al. 1991). Another strategy for providing sulfide oxidizing ectosymbionts with suitable environmental conditions has been suggested by Ott et al. (1998) and modified by Vopel et al. (2001) for a sedentary, feather-shaped, colonial peritrich ciliate that expands into oxygenated water and contracts into sulfidic water close to the substrate. The substrate is mangrove peat above which steep redox variations are present in the mm-range.

With regard to the strong adhesion capabilities of Leptonemella species, which can anchor themselves firmly to sand grains by means of caudal gland secretions, we propose the second strategy to be employed to fulfill the metabolic needs of their ectosymbionts. According to live observations of one individual over several hours, Leptonemella species may be considered to be hemisessile nematodes (see Riemann 1974), which may control the exposure of the ectosymbionts to oxic and sulfidic microzones, separated by steep gradients, just by alternate stretching and spiral curling of the long, filiform body. Migrations searching for these microzones are also possible, and the undulatory movements may effect the water exchange within the ectosymbiont layer.

According to the mode of attachment of their ectosymbionts, Stilbonematinae are classified into two groups. In one group, rod- and crescent-shaped bacteria are firmly attached to their host's cuticle in ordered monolayers. In the other group, to which the Sylt Leptonemella species belong, coccoid bacteria form multilayered sheaths, which may be easily detached (Polz et al. 1992). Though the bacteria in our material appeared to be embedded in a mucous matrix, they did not adhere firmly to one another and were liable to be washed away during the preparations. Because of this attribute, we cannot decide whether there are actually individuals without bacterial cover or whether all specimens that lack ectosymbionts have lost the bacteria during the isolation procedures. As, during moults of the hosts, the microbes are shed together with the old cuticle (Wieser 1959; Ott and Novak 1989), we may expect lifecycle stages without symbionts. A bacterial coat has been observed on even the smallest juveniles in the present material, thus the pertaining statement of Ott and Novak (1989) is confirmed.

Leptonemella species carry a comparatively voluminous bacterial coat (compare Ott and Novak 1989; Schiemer et al. 1990): the greatest extension is illustrated for Leptonemella sp. from Florida (Ott et al. 1982), where the thickness of the bacterial coat comes close to the diameter of the nematode. For the present material, we estimate a coat thickness of 5-10 $\mu \mathrm{m}$ on a Leptonemella with $25 \mu \mathrm{m}$ body diameter. Accordingly, we calculate for a nematode of $2000 \mu \mathrm{m}$ length a bacterial population of 1.25 to 2.93 million symbiont cells per worm. As to the size and arrangement of the symbionts, we considered for this calculation Fig. 9 in Giere (1992), an electron micrograph, which shows a section through $L$. gorgo. There are about 11 cells arranged within $10 \mu \mathrm{m}$. In our opinion, Leptonemella species that carry and foster millions of sulfide oxidizing bacteria may have a geochemical relevance for the sulfur cycling in sandy sediments.

Leptonemella species often contain bacteria in their intestines. Since Wieser (1959) suggested that stilbonematids may feed on their own ectosymbionts, this hypothesis has been followed up in several studies. Arguments in favor of the hypothesis are given by pointing to the similarities between intestinal and ectosymbiontic microbes (e.g. Jensen 1987b) and to stages of lysis in the intestine (Ott and Novak 1989; Ott et al. 1991). Jensen et al. (1992) consider that digestion occurs in the posterior part of the gut. Accordingly, in the present study bacteria were observed to be concentrated in the anterior part only of the intestine. Evaluation of ${ }^{13} \mathrm{C}$ depletion in stilbonematids (Ott et al. 1991) and, finally, observations of 'bare spots' within the layer of sulfide oxidizing ectosymbionts have been taken as an indication of the grazing activity of the nematode hosts (Polz et al. 1994). In contrast, live observations, including the present ones, have never supported this hypothesis. Moreover, experiments have shown that small holes in an otherwise intact coat of bacteria showed no signs of closure over a period of 7 days (Hentschel et al. 1999).

Acknowledgements We are grateful for the enthusiastic cooperation and support of Olav Giere and his collaborators from the University of Hamburg and of Nicole Dubilier and her colleagues and students from the Max Planck Institute for Marine Microbiology in Bremen. The hospitality of the staff from the Wattenmeerstation Sylt is gratefully acknowledged. We appreciate the comments on the manuscript of two anonymous reviewers.

\section{References}

Armonies W, Reise K (2000) Faunal diversity across a sandy shore. Mar Ecol Prog Ser 196:49-57

Bauer-Nebelsick M, Blumer M, Urbancik W, Ott JA (1995) The glandular sensory organ of Desmodoridae (Nematoda) — ultrastructure and phylogenetic implications. Invertebr Biol $114: 211-219$ 
Bayerl K, Köster R, Murphy D (1998) Verteilung und Zusammensetzung der Sedimente im Lister Tidebecken. In: Gätje C, Reise K (eds) Ökosystem Wattenmeer. Austausch-, Transportund Stoffumwandlungsprozesse. Springer, Berlin Heidelberg New York, pp 31-38

Bock LO (1999) Zur Ökologie thiobiotischer Nematoden. Bakteriensymbiontische und aposymbiontische Arten im Vergleich. Staatsexamensarbeit, Hamburg University

Boucher G (1975) Nématodes des sables fins infralittoraux de la Pierre Noire (Manche Occidentale). I. Desmodorida. Bull Mus Nat Hist Natl Paris (3) 285 (Zool 195):101-128

Cobb NA (1920) One hundred new nemas (type species of 100 new nematode genera). Contrib Sci Nematol (Baltimore) 9:217-343

Gätje C, Reise K (1998) Ökosystem Wattenmeer. Austausch-, Transport- und Stoffumwandlungsprozesse. Springer, Berlin Heidelberg New York

Gerlach SA (1950) Über einige Nematoden aus der Familie der Desmodoriden. Zool Anz Suppl 45 (Klatt-Festschrift, Neue Ergebnisse und Probleme der Zoologie):178-198

Gerlach SA (1958) Die Nematodenfauna der sublitoralen Region der Kieler Bucht. Kieler Meeresforsch 14:64-90

Gerlach SA (1964) Freilebende Nematoden aus dem Roten Meer. Kieler Meeresforsch 20 (Sonderheft):18-34

Giere O (1992) Benthic life in sulfidic zones of the sea-ecological and structural adaptations to a toxic environment. Verh Dtsch Zool Ges 85:77-93

Gourbault N, Vincx M (1990) Chromadorida (Nematoda) from Guadeloupe and Polynesia with evidence of intersexuality. Zool Scr 19:31-37

Hentschel U, Berger EC, Bright M, Felbeck H, Ott JA (1999) Metabolism of nitrogen and sulfur in ectosymbiotic bacteria of marine nematodes (Nematoda, Stilbonematinae). Mar Ecol Prog Ser 183:149-158

Hoschitz M, Buchholz TG, Ott JA (1999) Leptonemella juliae sp.n. and Leptonemella vestari sp.n. (Stilbonematinae), two new free-living marine nematodes from a subtidal sand bottom. Ann Naturhist Mus Wien 101 B:423-435

Hoschitz M, Bright M, Ott JA (2001) Ultrastructure and reconstruction of the pharynx of Leptonemella juliae (Nematoda, Adenophorea). Zoomorphology 121:95-107

Jensen P (1987a) Differences in microhabitat, abundance, biomass and body size between oxybiotic and thiobiotic free-living marine nematodes. Oecologia 71:564-567

Jensen P (1987b) Feeding ecology of free-living aquatic nematodes. Mar Ecol Prog Ser 35:187-196

Jensen P, Aagaard I, Burke jr RA, Dando PR, Jørgensen NO, Kuijpers A, Laier T, O'Hara SCM, Schmaljohann R (1992) 'Bubbling reefs' in the Kattegat: submarine landscapes of carbonate-cemented rocks support a diverse ecosystem at methane seeps. Mar Ecol Prog Ser 83:103-112

Lorenzen S (1974) Die Nematodenfauna der sublitoralen Region der Deutschen Bucht, insbesondere im Titan-Abwassergebiet bei Helgoland. Veröff Inst Meeresforsch Bremerh 14:305-327

Luc M, De Coninck LA (1959) Nématodes libres marins de la région de Roscoff. Arch Zool Exp Gén 98:103-165

Meyers MB, Fossing H, Powell EN (1987) Microdistribution of interstitial meiofauna, oxygen and sulfide gradients, and the tubes of macro-infauna. Mar Ecol Prog Ser 35:223-241

Ott JA (1995) Sulphide symbioses in shallow sands. In: Eleftheriou A, Ansel AD, Smith CJ (eds) Biology and ecology of shallow coastal waters. 28th European Marine Biology Symposium. Olsen \& Olsen, Fredensborg, Denmark, pp 143-147

Ott JA, Novak R (1989) Living at an interface: meiofauna at the oxygen/sulfide boundary of marine sediments. In: Ryland JS,
Tyler PA (eds) Reproduction, genetics and distribution of marine organisms. 23rd European Marine Biology Symposium. Olsen \& Olsen, Fredensborg, Denmark, pp 415-422

Ott J, Schiemer F (1983) Respiration and anaerobiosis of free living nematodes from marine and limnic sediments. Neth J Sea Res 7:233-243

Ott JA, Rieger G, Rieger R, Enderes F (1982) New mouthless interstitial worms from the sulfide system: Symbiosis with prokaryotes. PSZNI Mar Ecol 3:313-333

Ott JA, Novak R, Schiemer F, Hentschel U, Nebelsick M, Polz M (1991) Tackling the sulfide gradient: A novel strategy involving marine nematodes and chemoautotrophic ectosymbionts. PSZNI Mar Ecol 12:261-279

Ott JA, Bauer-Nebelsick M, Novotny V (1995) The genus Laxus Cobb, 1894 (Stilbonematinae: Nematoda): description of two new species with ectosymbiotic chemoautotrophic bacteria. Proc Biol Soc Wash 108:508-527

Ott JA, Bright M, Schiemer F (1998) The ecology of a novel symbiosis between a marine peritrich ciliate and chemoautotrophic bacteria. PSZNI Mar Ecol 19:229-243

Platt HM, Warwick RM (1988) Freeliving marine nematodes. Part II. British chromadorids. Pictorial key to the world genera and notes for the identification of British species. In: Kermack DM, Barnes RSK (eds) Synopses of the British fauna (new series) 38. Brill, Leiden (Published for the Linnean Society of London)

Polz MF, Felbeck H, Novak R, Nebelsick M, Ott JA (1992) Chemoautotrophic, sulfur-oxidizing symbiotic bacteria on marine nematodes: morphological and biochemical characterization. Microb Ecol 24:313-329

Polz MF, Distel DL, Zarda B, Amann R, Felbeck H, Ott JA, Cavanaugh CM (1994) Phylogenetic analysis of a highly specific association between ectosymbiotic, sulfur-oxidizing bacteria and a marine nematode. Appl Environ Microbiol 60:4461-4467

Reise K (1981) High abundance of small zoobenthos around biogenic structures in tidal sediments of the Wadden Sea. Helgoländer Meeresunters 34:413-425

Riemann F (1974) On hemisessile nematodes with flagelliform tails living in marine soft bottoms and on micro-tubes found in deepsea sediments. Mikrofauna Meeresboden 40:249-261

Riemann F (1988) Nematoda. In: Higgins RP, Thiel H (eds) Introduction to the study of meiofauna. Smithsonian Institution Press, Washington DC, pp 293-301

Scheibel W (1973) Quantitativ-ökologische Untersuchungen am uferfernen Mesopsammon in der Kieler Bucht. Kieler Meeresforsch 29:58-68

Schiemer F, Novak R, Ott J (1990) Metabolic studies on thiobiotic free-living nematodes and their symbiotic microorganisms. Mar Biol 106:129-137

Vopel K, Pöhn M, Sorgo A, Ott J (2001) Cilate-generated advective seawater transport supplies chemoautotrophic ectosymbionts. Mar Ecol Prog Ser 210:93-99

Warwick RM (1981) Survival strategies of meiofauna. In: Jones NV, Wolff WJ (eds) Feeding and survival strategies of estuarine organisms. Plenum Press, New York, pp 39-52

Wetzel MA, Jensen P, Giere O (1995) Oxygen/sulfide regime and nematode fauna associated with Arenicola marina burrows: new insights in the thiobios case. Mar Biol 124:301-312

Wieser W (1959) Eine ungewöhnliche Assoziation zwischen Blaualgen und freilebenden marinen Nematoden. Österr Bot Z 106:81-87 